\title{
Discourse and Social Values in Oprah Winfrey Show Hosting Queen Rania of Jordan
}

\author{
Hala El Saj \\ Holy Spirit University of Kaslik, Kaslik - Lebanon \\ hala_saj@hotmail.com \\ Charles M Sarraf \\ Holy Spirit University of Kaslik, Kaslik - Lebanon \\ charlessarraf@usek.edu.lb
}

\section{Doi:10.5901/mjss.2013.v4n11p289}

\section{Abstract}

The analysis of values in textual structures is relevant in three overlapping areas. First, representations of social reality in discourse (and in sociological interpretations of discourse) are always value-related. Second, the definition of positive identities of the speaker as people who know and can be trusted, involves values that must be generated not only inter- or extratextually but also in the structures of the text itself. Third, the arousal of emotions or even passion is based on values that are present but often hidden in textual structures. This paper investigates the values discussed in Oprah Winfrey episode hosting Queen Rania of Jordan, addressing the following question: how the social values of Oprah Winfrey and Queen Rania of Jordan were revealed in the episode? The transcript was analyzed based on Faiclough model for Critical Discourse Analysis and his contextual dimension approach of discourse. The results suggest that experiential values were revealed in Queen Rania's dialogue using overwording and rewording. Relational values were revealed through formality of relation, as Oprah Winfrey expressed politeness, respect for the Queen's status and position. Expressive values were shown in the Queen's dialogue expressing herself as a subject who has a position as a Queen, and her own social identity as Jordanian women. Oprah Winfrey and Queen Rania draw upon personal pronouns dichotomy by classifying people into categories built upon each one ideological representation of reality.

\section{Introduction}

The term discourse refers precisely to the capacity of meaning-making resources to constitute social reality," forms of knowledge and identity within specific social contexts and power relations" (Hall, 1997, p.220). Fairclough (1992) suggested that we can distinguish three aspects of constructive effects of discourse. Discourse contributes first of all in the construction of what are variously referred to as 'social identities' and 'subjects positions' for social 'subjects' and types of 'self'. In other words, discourse constructs social identity, by defining groups, group's interests, their position within society and their relationship to other groups (cited in Wodak, 1995, p.126).

According to Fairclough, critical language study (CLS) conceptualizes language as a type of social practice. He defines the term discourse as "practice, which is discoursal, meaning actual talk or writing. Interdependent networks within discourse and practice are called orders of discourse and orders of practice" (Fairclough 2001, pp.34-35). The social roles are always in accordance to situation and context. They are connected to particular social positions as e.g. a student and teacher, in which there are certain ideals and requirements that must be followed. These positions are termed "subject positions". They continue to be a part of social structure through the continuation of the same subject positions (Fairclough 2001, pp.30-33).

\section{Aim of the study}

This paper investigates the values discussed in Oprah Winfrey episode hosting Queen Rania of Jordan, addressing the following question: how the social values of Oprah Winfrey and Queen Rania of Jordan were revealed in the episode? The data selected for this study is the interview of Oprah Winfrey with Queen Rania of Jordan, dated on May 17, 2006. 


\section{Theoretical background}

The analysis of values in textual structures is relevant in three overlapping areas. First,representations of social reality in discourse (and in sociological interpretations of discourse) are always value-related. Whether we talk about sex, gender, ethnicity, war, or public health, our conceptual systems are invested with values, albeit often tacitly and in an invisible way ( Sulkunen \& Torronen, 1997). This is one of the most important mechanisms of persuasion, not only in political texts but also in scientific discourse (Atkinson 1990). Second, the definition of positive identities of the speaker - for exampleas people who know and can be trusted- involves values that must be generated not only inter- or extra- textually but also in the structures of the text itself. Third, the arousal of emotions or even passion is based on values that are present but often hidden in textual structures (Sulkunen \& Torronen, 1997). In traditional content analysis, values are usually conceived as an element of what Fairclough (1992a) calls the contextual dimension of discourse. For him, texts "are seen to represent values embedded in ideology, attitudes, or power relationships outside the text" (p.193). Fairclough's appeal to combine contextual analysis of the content to intra textual form is particularly relevant in the analysis of values (Fairclough, 1992a).

Unlike knowledge, ideologies are systems of social cognition that are essentially evaluative: they provide the basis for judgments about what is good or bad, right or wrong, and thus also provide basic guidelines for social perception and interaction. It is therefore assumed that the basic building blocks of ideologies are sociocultural values, such as equality, justice, truth or efficiency. Typically, such values are not limited to specific groups, but have broader cultural relevance. This means that they may be culturally specific and culturally variable, although some values may be universal (Hofstede, 1980; Rokeach, 1973, 1979). Each social group is assumed to make a self-interested selection from these values, and assigns a hierarchy of relevance to them as a function of its social position and goals for each group. These values, as Dijk (1995) states, may be expected to "constitute the basic evaluative criteria for the opinions that define ideological systems" (p.248).

\section{Critical discourse analysis in practice}

When applying critical discourse analysis to content, the aim is to uncover the text's embedded values in order to reveal any hidden ideological frameworks operating within a given case. Fairclough (1995a) argues that using a critical approach to discourse analysis tries to make visible the connections between properties of texts and social processes and relations, which are not obvious to the actual producers and interpreters of these texts. However, in practice interviews are as complex and vivid as any other type of interaction, and responses to answers which may seem neutral and non-committal in the abstract may have an important impact on the trajectory of the interaction.

Discourse in this sense refers to" the language used in representing a given social practice from a particular point of view" (Fairclough, 1995b, p. 56), whether it is written or spoken language (Fairclough 1995a). Moreover, interviews have been used extensively in discourse analytic work because they allow a relatively standard range of themes to be addressed with different participants — something hard to achieve when collecting naturalistic materials. Discourse, as argued by Jager (2001)," is not created by one individual; it is a historical process which evolves through time" (p. 37). According to this view" the values and norms and laws and rights, which are based in analysis, are the historical outcome of discourse" (Jager, 2001, p.34).

Fairclough (2001) distinguishes between three different values of a text, namely experiential, relational and expressive. These are applicable at any level - word, grammatical or cohesive level - of the critical discourse analysis.

The meaning of experiential values "reflects the knowledge and beliefs of the producer in question, which is evident in the choice of wordings". The terminological choices of texts are often the most ideological pointers within it since some words are "unconsciously associated with certain ideological frameworks" (Fairclough, 2001, pp.94-95). Thus, as Fairclough adds, "the occurrence of particular words will uncover the discourse types the words are drawing upon and contributing to" (Fairclough, 2001, p.95).

One particular sign of an ideological framework within a text is over-wording. "Overwording indicates preoccupation with certain aspects of reality, which may reveal an ideological struggle" (Pierce, 2008, p.293). It includes three main meaning relations, namely synonymy, hyponymy and antonymy (Jackson, \& Amvela, 2004). In synonymy words have the same meaning. However, it may be difficult to find words with exactly the same connotation, so in actuality one is looking for near synonymy between words (Wanne, 1996). In hyponymy the meaning of one word is embedded in the meaning of another word in one ideological discourse type (Hudson, 2004), whereas antonym implies meaning incompatibility between words (Allan \& Brown, 2009). 
Experiential values of a text may be analyzed by examining its classification schemes. A classification scheme is a particular way of dividing up some aspects of reality, which are structured upon ideological characteristics the words have in common. In this way, "the structure of a vocabulary, namely synonymy, hyponymy and antonym, is ideologically based" (Fairclough, 2001, pp. 96-97).

The idea of relational values reflects how a text's choice of wordings depends on and creates social relationships between members of a particular group (Abe, 2000). For example, "the use of pro-anorectic vocabulary such as the inspiration entails experiential value in terms of a pro-anorectic representation of a grouping, but its use may also have relational value, assuming that such pro-anorectic ideology is common ground for the speaker and other participants" (Fairclough, 2001, p.98). Fairclough adds that the text producer may "not always be aware of the relational values his or her text is establishing as he or she often adopts strategies to avoid negative values of words for relational reasons" (Fairclough, 2001, p.98).

A text producer evaluates the reality the text treats through the vocabulary, namely the expressive values. Fairclough (2001) states that expressive values are interconnected with experiential values; "the experiential values represent the text producer's knowledge and ideas, while the expressive values represent the text producer's way of judging" (Fairclough, 2001,p.99). According to Fairclough, "the text producer's evaluations are expressed by drawing on classification schemes, which are ideologically significant" (Fairclough, 2001, p.99).

\section{Methodology}

In this study the data will be analyzed first based on the three overlapping areas mentioned by Sulkunen and Torronen, (1997), including representations of social reality, positives identities, and arousal of emotions. Next, the chosen data will be analyzed through Critical Discourse analysis (CDA) as a main tool ,using Fairclough (2001) presentation model for $\mathrm{CDA}$, distinguishing specific elements of the critical discourse analysis theory including experiential, relational and expressive values of words, which are relevant for our transcript. In addition to Fairclough $(1992,1996)$ contextual dimension approach of discourse.

\section{Analysis and Results}

\subsection{Discourse and Social Values}

Language is a resource for the creation and maintenance of social relations and value systems. Every discourse voice, embodied in text, constructs a stance towards itself and other discourse voices." It evaluates, explicitly or implicitly, what it has to say and the relation of what it has to say to what others do say or may say. Its evaluative orientation includes, but is not limited to, certitude or truth value. It can define any value orientation toward what it says and/or toward what others say: appropriateness, usefulness, morality, pleasurability; all the forms of'rightness' and 'goodnes' '(Lemke, 1988, p.2).

Beginning with the three overlapping mentioned before. First Queen Rania represented a social reality in her discourse, like in the following utterances:

Queen Rania:" When the honest truth is that my life is very much about dealing with issues on the ground." Here the Queen reveals the value of honesty to deal with her social position and reality as Queen.

Queen Rania:" A lot of the problems that our country faces. And that's something I do on a daily basis.". Here she is talking about ethnicity and her country, the fact that she is a queen and she deals with the problems of her country on a daily basis.

Atkinson (1990) stated that our conceptual systems are invested with values, albeit often tacitly and in an invisible way. This is one of the most important mechanisms of persuasion, and it is obvious in the following utterance said by Queen Rania: "Because once she has the education, she can then have control over her income, she can change her life, she can have choices. And I truly believe that education--and when we talk about poverty, in my mind, poverty is a she. You know, so many women around the world are just condemned to a life...". Another instance where value is embedded, and persuasion remains invisible is:" And this is not true. As long as a woman is wearing it because of her belief. And I always say we should judge women according to what's going on in their heads rather than what's on top of their heads". Oprah by replying "very good for you, yeah", gives a reflection being persuaded by the values offered by the Queen.

Second, the definition of positive identities of the speaker. According to the virtue perspective, an identity is 
positive when "it is infused with the qualities associated with people of good character, such as master virtues, like wisdom, integrity, courage, justice, etc.."(Park \& Peterson, 2003, p.33).Oprah Winfrey and Queen Rania as someone who knows and can be trusted involves virtue values:

Oprah Winfrey:" You know, I believe in educating girls, too. And I love your-l quote you all the

time when you say educating a girl, you educate the future.

Queen Rania:" Absolutely."

Oprah Winfrey: "Yes. "

Queen Rania:" And one of the most important things that you can do for a girl is to empower her with her education."

Oprah Winfrey: "That's...(unintelligible)."

Here both Oprah and Queen Rania has positive identities, the fact that they encourage women to be more educated both have the value of courage and wisdom, to reinforce the thought of empowering women by education.

Third contextual dimension of discourse so called by Faiclough (1992a). Texts are seen to represent values embedded in ideology. Dimension is a personalized framing reflecting the way in which participants formulate their ideas, overtly expressing their own perspective that frames statements. For example, mental verbs express (think, know, suppose, guess..) the personal state of mind (Upton, 2007), which is revealed in the following utterances lines

"Queen Rania: "I think what would surprise most people is just how alike we are. You know, and this is something I have found out through my travels. Whether I'm in China, India, Africa,

United States or Europe, you walk into a room and you meet someone and you think you're going to be so different. But once you go beyond the mannerisms, the language, the cultural idiosyncrasies, you realize that you're basically the same, you know? ". Here the use of mental verb accompanied with the personal pronoun I express the state of mind of the Queen that going beyond the cultural difference she realizes that people are the same they are alike.

Moreover if something has the same value or worth for all, or almost all, people, is of universal value. This claim could imply two important different means. First, it could be that something has a universal value when everybody finds it valuable. This was Isaiah Berlin's understanding of the term. According to Berlin, as cited by Jahanbegloo (1991) "...universal values.... are values that a great many human beings in the vast majority of places and situations, at almost all times, do in fact hold in common, whether consciously and explicitly or as expressed in their behavior..." (p.37). Second, something could have universal value when all people have reason to believe it has value. Throughout the conversation valuable utterances reflect a great deal of universal values:

Queen Rania: Mothers are mothers all over the world. They want the best for their kids.

Oprah Winfrey: Mothers are mothers. Kids, yeah.

Queen Rania: They want to have dignity, their rights.

Oprah Winfrey: That's true.

The fact that mothers are mothers and kids are kids, is a universal ideology existed in both culture the one of Oprah Winfrey and the Queen.

\subsection{Experiential value of vocabulary:}

"A formal feature with experiential value is a trace of and a cue to the way in which the text producer's experience of the natural or social world is represented. Experiential value is to do with contents, knowledge, and beliefs." (Fairclough 2001, p.93). This quote means that when writing a text, the author will automatically choose words, which to a certain degree, will reflect his own worldviews. In this connection, we see the deciphering of these worldviews to be reliant on the social and cultural understandings of the receivers.

There are experiential values connected to the words in the Queen's usage of such phrases as: "The day I found out that I was going to be in this position, it was really terrifying because I had self-doubt. I wasn't particularly sure-footed. I didn't know what was going to happen to my life or what would happen to my children, you know" can be read in terms of representing, what Fairclough refers to as, overwording (Fairclough, 2001) and show the Queen's concern or, preoccupation with the problem that she is discussing. The two phrases both have negation constituents and can be interpreted as that she wants to stress her point which is deduced from the fact that the phrases occur in utterances following each other.

The synonyms are occurred in two shapes Overwording mentioned above and the Rewording occurred in the repetition of educating girls, these utterances are naturalized in a conscious and systematic way. The aspects of overwording and rewording can help us find the experiential values presented by the characters in the different scenes. 
Generally, it is useful as it helps us to find different systems of belief in the conversation that we analyze. The occurrence of antonym and hyponymy within the conversation between Queen Rania and Oprah Winfrey doesn't exist. Seems that both women agreed on the values offered from their both sides.

\subsection{Relational value of vocabulary:}

Here the main matter is relational values as explained prior to this, it deals with the way a text's selection of words rely on and assist in creating societal relations among members of a given society it includes features of formality. Introduced by Fairclough(1996),"formality is a common property in many societies of practices and discourses of high social prestige and restricted access"(p.65). The term formality covers the use of words of a ceremonial, professional, conventional, or traditional nature usually connected to a certain social instance or status example the opening scene of Oprah introducing the Queen:

Oprah Winfrey:" She is the world's youngest queen, and we're honored to have her here.

Please welcome her Royal Majesty Queen Rania. "The formality of the situation here demands formality of relations and this evident in the vocabulary, which consistently opts for more formal choices against less formal available alternatives. Expressing politeness, respect for status and position. Noticing the polite title + surname modes of address that are used her Royal Majesty Queen Rania.

\subsection{Expressive value of vocabulary}

"A formal feature with expressive value is a trace of and a cue to the producer's evaluation (in the widest sense) of the bit of the reality it relates to. Expressive value is to do with subjects and social identities [...]" (Faiclough, 1996, p.93). Expressive values are important to this project as it evaluates the identities within the given text and places them between the qualities of either virtuous or vice.

The expressive values of words can cooperate with the feature of classification schemes in constructing social identities represented in the conversation. Hereby it partakes in depicting the different ideologies connected to the different characters. They are evident in some phrases expressed by Queen Rania where she uses categorizations such as their problems, somebody else creating a distance between her and people living in this area. Furthermore, this is also a way of distancing the ideology of the Queen from that of others.

Another expressive value is represented in the answer of Queen Rania concerning wearing the veil, where her answer was "it's a personal choice". Here the Queen presents her own opinion and evaluation of wearing the veil as it is a part of reality, thus expressing herself as subject who has a position as Jordanian Queen within her social relations present in society. Also she expressed her own social identity as a Jordanian Queen representing the Jordanian Muslim women by using the pronoun we.

Following up another instance of expressive value when the Queen evaluates raising up her 12 years boy by instill him with the right values, where she describes values as the shield.

The evaluation that takes place here provides a clear representation of how she views the role of values.

Queen Rania and Oprah Winfrey draw upon I/we/us, you/your dichotomy by classifying people into these categories. They use personal pronouns, which indicate their preoccupation with the issue of identity. One can say that she is drawing upon a classification scheme (Fairclough,2001, p.96) as they split a given element of "reality, built upon a particular ideological representation of that reality"( Fairclough,2001,p.96) in this case the 'reality' refers to people and the ideology that people should be unique, and not like everybody else. This can be detected from the mere fact that each one makes the categories of 'us' throughout her use of discourse.

\section{Conclusion}

In the foregoing interview, we have examined the values revealed by Queen Rania of Jordan and Oprah Winfrey. In the interview, Queen Rania expressed her experiential values by using overwording and rewording. Expressive values were shown in the Queen's dialogue expressing herself as a subject who has a position as a Queen, and her own social identity as Jordanian women. Oprah Winfrey revealed relational values through formality of relation, as she expressed politeness, respect for the Queen's status and position. Both women shared common values such as educating girls and empowering women, as the culture plays a very important role in the spreading of common values, which are described by Hofstede as 'universal values'. In addition, Oprah Winfrey and Queen Rania draw upon personal pronouns dichotomy 
by classifying people into categories built upon each one ideological representation of reality. It is possible to say that these kinds of ideologies that Oprah Winfrey and Queen Rania spread are important to the maintenance of the crosscultural dialogue.

\section{References}

Abe, H. (2000). Speaking of power: Japanese professional women and their speeches. UK: Lincom.

Allan, K. \& Brown, K. (2009). Concise Encyclopedia of Semantics .UK: Elsevier Ltd.

Atkinson, P. (1990). The Ethnographic Imagination: Textual Constructions of Reality. London and New York: Routledge.

Biber, D., U. Connor \& T. Upton.(2007). Discourse on the move: Corpus- based investigations of discourse structure. Amsterdam: John Benjamins.

Dijk, T.A. (1995). Discourse Analysis as Ideology Analysis. In Christiina Schaffner and Anita L. Wenden (eds.). Language and Peace. Pp.17-33. Dartmouth: Aldershot.

Fairclough, N. (1992a) Discourse and Text: Linguistics and intertextual analysis within discourse analysis. Discourse and Society, 3(2). 193-217.

Fairclough, N. (1995a). Critical Discourse Analysis: The critical study of language. London, UK: Longman.

Fairclough, N. (1995b). Media discourse. London: Edward Arnold.

Fariclough, N. (1996). A reply to Henry Widdowson's "Discourse analysis: a critical view". Language and Literature, 1996, 5 (1): $49-56$

Fairclough, N. (2001). Language and Power. 2nd Edition. London: Longman

Hall, S. (1997). Representation, meaning, and language. In S. Hall (Ed.), Representation. Cultural Representations and Signifying Practices. Pp. 15-30. London: Sage Publications.

Hudson, K. (2004). Word Meaning. UK: Routledge.

Jackson, H. \& Amvela, E. (2004). Words, meaning and vocabulary: an introduction to modern English lexicology.UK: Cromwell Press.

Jäger, S. (2001). Discourse and knowledge: Theoretical and methodological aspects of a critical discourse and dispositive analysis. In: R. Wodak \& M. Meyer (Eds.), Methods of critical discourse analysis (pp. 32-62). London: Sage Publications.

Jahanbegloo, R.( 1991).Conversations with Isaiah Berlin. New York: Scribner.

Lemke, J.L. (1988). Discourses in Conflict: Heteroglossia and Text Semantics. Systemic Functional Approaches to Discourse. Ed. J.D. Benson \& W.S. Greaves. Norwood, NJ: Ablex Publishing.

Park, N., \& Peterson, C. (2003). Virtues and organizations. In K. S. Cameron, J. E. Dutton, \& R. E. Quinn (Eds.), Positive organizational scholarship: Foundations of a new discipline (pp. 33-47). San Francisco: BerrettKoehler

Pierce, R. (2008). Research methods in politics: a practical guide. London: Sage.

Sulkunen, P. \& Torronen, J. (1997). The production of values: The concept of modality in textual discourse analysis. Semiotica- Journal of the International Association for Semiotic Studies, Volume 113: (1-2)

Wanne,L. (1996). Lexical functions in lexicography and natural language processing. USA: John Benjamins Publishing Company.

Wodak, R. (1995). Critical Linguistics and Critical Discourse Analysis. In Jef Verschuren, Jan-Ola Ostman, and Jan Blommaert (eds.). Handbook of Pragmatics-Manual. Amsterdam:

John Benjamins Publishing Company. 